УДК 675.92: 620.2

А.В.ДЗЮБИНСЬКИЙ, О.В.ДЗЮБИНСЬКА, О.Ю.РЕЧУН

Луиький наиіональний технічний університет

\title{
ПРОБЛЕМИ ТА ПЕРСПЕКТИВИ РИНКУ КИСЛОМОЛОЧНИХ ПРОДУКТІВ
}

\author{
А.В.ДЗЮБИНСКИЙ, О.В.ДЗЮБИНСКАЯ, О.Ю.РЕЧУН
}

Луикий национальный технический университет

\section{ПРОБЛЕМЫ И ПЕРСПЕКТИВЫ РИНКА КИСЛОМОЛОЧНЫХ ПРОДУКТОВ}

\section{A. DZIUBYNSKIY, O. DZIUBYNSKA, O.RECHUN}

Lutsk national technical university

\section{PROBLEMS AND PERSPECTIVES OF THE MARKET OF SOUR-MILK PRODUCTS}

\section{https://doi.org/10.36910/6775-2310-5283-2018-11-03}

Мета. Дослідження динаміки розвитку ринку кисломолочної продукції, а також факторів, щуо впливають на споживні властивості продукту та його привабливість.

Методика. Для визначення показників споживних властивостей використовували органолептичні, фізико-хімічні та мікробіологічні методи дослідження відповідно до діючої нормативної документації України. Дослідження ринку проводили за стандартними методиками.

Результати. Проаналізовано існуючи підходи щодо поліпшення якості досліджуваного продукту. Одним із способів підвищення споживних властивостей визначено корегування якості із застосуванням різноманітних наповнювачів, наприклад, компонентів тваринного (молоко, закваски, сир) та рослинного (фрукти, ягоди, овочі, спеціï) походження. Крім иъього ще одним иляхом підвищення харчової иінності кисломолочних продуктів є збагачення їх складу білковими, вуглеводними та мінеральними компонентами.

Практична значимість. Отримані результати досліджень можуть бути використані в роботі вітчизняних підприємств-виробників молочної продукції.

Ключові слова: кисломолочна продукиія, дефекти, якість, споживні властивості, ринок.

Постановка проблеми у загальному вигляді і її зв'язок з важливими науковими та практичними завданнями. Зниження обсягів виробництва 
молочної продукції, насамперед, пов’язано зі зниженням споживання молока та молокопродуктів на душу населення внаслідок зниження платоспроможності населення та підвищення цін реалізованої продукції, а також втрату ринку Росії. 3 огляду на зниження попиту на кисломолочну продукцію необхідно провести узагальнення досліджуваних робіт для більш чіткого окреслення сучасного стану ринку кисломолочних товарів, їх якості та безпечності, а також споживчих та фізіологічних властивостей, відповідності встановленим національним та європейським стандартам.

Аналіз останніх досліджень, у яких започатковано вирішення проблеми. Проблеми, пов'язані із якістю, безпечністю та конкурентоспроможністю кисломолочної продукції України відображені в працях таких дослідників: Б. Голуб, Н. Дідух, I. Донцова, Н. Джурик, І.Орлова, С.Пономарьов, Т. Шкабара, О.Щербак, О.Якубчак, та ін. Науковцями та практиками розглядаються питання технічного й технологічного забезпечення якості кисломолочних продуктів, аналізується стан ринку і перспективи його розвитку.

Цілі статті - дослідити сучасний стан ринку кисломолочної продукції України та оцінити його перспективи.

Об’єкт дослідження - ринок кисломолочної продукції України

Виклад основного матеріалу дослідження 3 повним обгрунтуванням отриманих наукових результатів Дослідження світового ринка молока показало, що виробництво постійно зростало протягом минулих десятиліть, додаючи щороку в середньому 2 \%. Ще у 2015 воно досягло 800 млн. тон. Найбільшими виробниками є $\mathrm{CC}$, Індія і США які втрьох виробляють половину молока в світі. Китай виробляє лише 5\% і ділить 3 Пакистаном 4 і 5 місця. Україна знаходиться в другій десятці найбільших країн-виробників 3 обсягом 10,6 млн. тон і має частку 1,3 \% в світовому виробництві.

Найбільшу частку у виробництві молочної продукції має масло - понад $50 \%$ від всього загального обсягу виробництва. Друге місце належить жирним сирам - 20 \%, на молоко та кисломолочні продукти припадає $10 \%$. Динаміку виробництва основних молочних продуктів в Україні можна побачити на рис.1.

В останні роки скоротилося виробництво молока обробленого, жирних сирів, сухого молока і незначно кисломолочної продукції, проте помітно збільшилося виробництва сиру кисломолочного та казеїнів. 


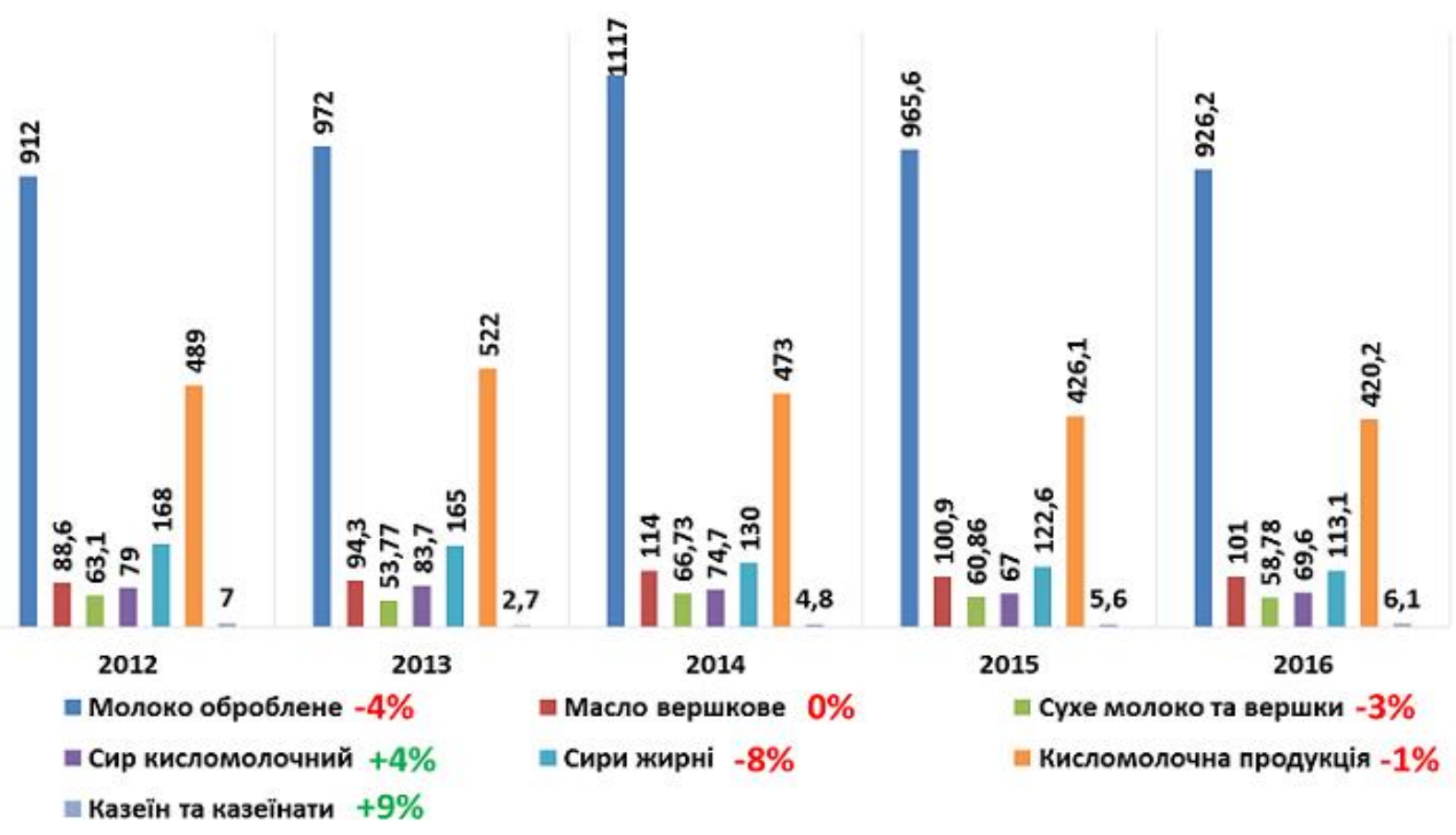

Рис. 1. Динаміка виробництва основних молочних продуктів в Україні, тис. тон.

Структура експорту та імпорту молочної продукції України у 2015-2016 pp. наведена у табл. 1 .

Таблиця 1

Структура експорту та імпорту молочної продукції України у 2015-2016 pp., тон

\begin{tabular}{|l|c|c|c|c|c|c|c|c|}
\hline \multirow{2}{*}{$\begin{array}{c}\text { Найменування } \\
\text { продукції }\end{array}$} & \multicolumn{3}{|c|}{ Експорт } & \multicolumn{3}{c|}{ Імпорт } & \multicolumn{2}{|c|}{$\begin{array}{c}\text { Екс. до імп., } \\
\text { разів більше }\end{array}$} \\
\cline { 2 - 10 } & 2016 & 2015 & $\begin{array}{c}16 / 15, \\
\%\end{array}$ & 2016 & 2015 & $16 / 15, \%$ & 2016 & 2015 \\
\hline $\begin{array}{l}\text { Молоко і } \\
\text { вершки }\end{array}$ & 5787 & 5795 & $99,9 \%$ & 310 & 213 & $145,5 \%$ & 18,67 & 27,21 \\
\hline Молоко згущене & 39143 & 39037 & $100,3 \%$ & 620 & 337 & $184,0 \%$ & 63,13 & 115,84 \\
\hline Кисломол. прод. & 2068 & 2456 & $84,2 \%$ & 1647 & 2113 & $77,9 \%$ & 1,26 & 1,16 \\
\hline Мол. сироватка & 16684 & 17845 & $93,5 \%$ & 420 & 689 & $61,0 \%$ & 39,72 & 25,90 \\
\hline Масло тваринне & 6395 & 8004 & $79,9 \%$ & 872 & 154 & $566,2 \%$ & 7,33 & 51,97 \\
\hline Сири & 4798 & 4784 & $100,3 \%$ & 4307 & 3274 & $131,6 \%$ & 1,11 & 1,46 \\
\hline Морозиво & 4148 & 4055 & $102,3 \%$ & 89 & 102 & $87,3 \%$ & 46,61 & 39,75 \\
\hline Казеїн & 4512 & 4256 & $106,0 \%$ & 51 & 33 & $154,5 \%$ & 88,47 & 128,97 \\
\hline $\begin{array}{l}\text { Зартість тис. } \\
\text { дол }\end{array}$ & 126478 & 140786 & $89,8 \%$ & 26591 & 21123 & $125,9 \%$ & 4,76 & 6,67 \\
\hline
\end{tabular}


3 таблиці зрозуміло, що поряд із скороченням виробництва, скорочується і обсяг експортованої продукції. Суттєвого зниження експорту зазнали молочна сироватка, масло тваринне та кисломолочна продукція, що зменшило дохід у грошовій формі на 10 \%. Інші види продукції, чиї обсяги збуту залишились на рівні минулого року або збільшились на дохід у грошовій формі вплинули незначно. Варто відзначити, що поряд із скороченням експорту на $10 \%$, на $25 \%$ зріс імпорт молочної продукції, а саме: сирів - більше ніж на 1 тис. тон, тваринного масла - у 5,5 разів та молока згущеного - майже у 2 рази.

Що ж стосується кисломолочних продуктів то відбулося зниження як експорту так і імпорту цієї групи продукції. Експерти ринку визнають, що основною конкурентною перевагою наших продуктів $є$ ціна, яка дозволяє продавати на вимогливих ринках (наприклад $\mathrm{CC}$ ), однак проблема забезпечення якості кисломолочних продуктів залишається.

3 огляду на ситуацію на ринку можна виділити декілька аспектів та проблем в досягненні європейських показників якості багатьма вітчизняними підприємствами, головною з яких $є$ проблема якості початкової сировини молока (що відбивається на готових продуктах, які дуже часто не відповідають навіть встановленим національним стандартам). Це пояснюється тим, що переважаюча частка молочної продукції на сучасний ринок постачається із приватних домогосподарств, в яких використовується лише ручне доїння. Звідси потенційна та реальна можливість бактеріального забруднення молока. Крім того, додаються проблеми на етапах перевезення продукції тощо.

Іншою перепоною у досягненні якості, на нашу думку, є питання належної переробка молока та виготовлення кисломолочної продукції із використанням сучасних технологій, обладнання та устаткування.

Сьогодні дедалі популярнішими в споживачів стають продукти 3 різноманітними наповнювачами. У виробництві кисломолочних продуктів із наповнювачами як сировину використовують компоненти тваринного (молоко, закваски, сир) та рослинного (фрукти, ягоди, овочі, спеції) походження. Використання в рецептурі зернобобових та злакових культур також підтримує поширену концепцію підвищення харчової цінності кисломолочних продуктів. Аналіз останніх досліджень і публікацій показав, що працями зарубіжних та вітчизняних учених доведено, що споживачі кисломолочної продукції - переважно люди, які слідкують за своїм здоров’ям. Вони дотримуються раціонального харчування та прагнуть споживати 
продукти 3 підвищеною харчовою цінністю. Дослідниками доведено, що одним шляхів підвищення харчової цінності кисломолочних продуктів $\epsilon$ збагачення їх складу білковими, вуглеводними та мінеральними компонентами. Через популярність серед населення країни та досить високу біологічну цінність протягом останніх років спостерігається стабільний попит на споживання сиру кисломолочного різної жирності. Це визначено його повноцінним складом, високою засвоюваністю компонентів, що доречно зауважити, мають значний потенціал до вдосконалення. Слід зазначити, що для споживачів особливе значення мають органолептичні властивості будьякого харчового продукту та кисломолочних зокрема. У контексті актуальності світової концепції підвищення харчової цінності продуктів харчування та з урахуванням принципів раціонального та збалансованого харчування доцільно використання в рецептурі кисломолочних продуктів рослинних компонентів, а саме - злакових та зернобобових культур, внесення яких сприятиме збагаченню складу та покращенню органолептичних властивостей традиційного кисломолочного продукту - сиру.

Найчастіше у дослідженні як основну сировину використовують кисломолочний сир із вмістом жиру $9 \%$, збагачувачами виступають гречане борошно та зернобобова культура нут. Розроблені нові кисломолочні продукти, які віднесено до сегмента продуктів раціонального харчування, вміщують повноцінні білки (ураховано наявність/відсутність лімітованих амінокислот). Для збалансування їх амінокислотного складу до кисломолочної основи додають гречане борошно. Гречане борошно має повноцінний склад, зокрема, у ньому міститься в 3-5 разів більше мікроелементів (заліза, калію, фосфору, міді, цинку, кальцію, магнію, бору, йоду, нікелю та кобальту), ніж у інших крупах; під час введення до кисломолочної основи гречане борошно виконує стабілізаційну функцію.

Серед зернобобових культур сьогодні набуває популярності нут, який відрізняється від інших раціональним комплексом речовин рослинного походження, а саме: біологічна цінність білків нуту (а в перерахунку на 100 г білка за кількістю незамінних амінокислот він переважає над іншими бобовими культурами) зумовлена доступністю амінокислот і збалансованим амінокислотним складом; його гідрофільні властивості виконують функцію стабілізації консистенції в кисломолочній основі нових продуктів. Позитивний вплив рослинних добавок до кисломолочного сиру (основи комбінованого продукту) полягає в збільшенні вмісту незамінних амінокислот таких, як метіонін і цистин, що, безумовно, вплинуло на його біологічну 
цінність. Поряд із цим, для нових кисломолочних продуктів із гречаним борошном i нутом досліджено та розраховано кількість вітамінів та мінеральних речовин порівняно з традиційним видом кисломолочному сиру. Хімічний склад нового кисломолочного продукту 3 нутом збагачується вітамінами Е, В6, тіаміном, мікроелементами - калієм, кремнієм, магнієм, сіркою, фосфором, залізом, алюмінієм, ванадієм, йодом, кобальтом, марганцем, міддю, молібденом, нікелем, хромом, цинком. Але дослідження хімічного складу нових кисломолочних продуктів 3 додаванням рослинної зернової та зернобобової сировини вимагає поглиблених випробувань.

Висновки та перспективи подальших досліджень. Головні проблеми, які на сьогодні характеризують молокопереробну галузь, є: зменшення обсягу виробництва молока в Україні протягом останніх років; відносно низька якість молока, яка надходить на переробку, що часто призводить до вибракування сировини, а відповідно зменшення продуктів переробки молока, зокрема кисломолочних.

Впровадження європейських стандартів у діяльність молочної галузі України потребуватиме від виробників молока i молочної сировини проведення таких заходів: здійснення реконструкції існуючих i побудови нових молочних ферм, які відповідали б стандартам $\mathrm{EC}$; приведення методів і процедур контролю за безпечністю i якістю молочної сировини у відповідність з вимогами $\mathrm{EC;} \mathrm{збільшення} \mathrm{частки} \mathrm{молока} \mathrm{гатунку} \mathrm{«екстра»} \mathrm{у}$ загальному обсязі молочної продукції; удосконалення системи професійного навчання персоналу, задіяного у виробництві молочної сировини, молока i молокопродуктів; адаптація процедури дослідження води на підприємствах молочної галузі для забезпечення параметрів СС.

\section{Бібліографія}

1. Ізбаш Є. О. Розробка параметрів підготовки зернових добавок для виробництва молочно-рослинних продуктів / Є. О. Ізбаш, В. О. Моргун, Н. Г. Марінєску // Наукові праці ОНАХТ. Сер. Технічні науки. - Одеса : ОНАХТ, 2010. - Вип. 38, т. 2. - С. 265-268.

2. Дідух Н.А. Медико-біологічні досліди йогурту / Н.А. Дідух, Н.А. Могилянська // Продукты и Ингредиенты - 2009. - №11. - С.46-47.

3. Донцова І.В. Кисломолочні продукти підвищеної біологічної цінності / I.В. Донцова, В.Т. Лебединець, Л.І. Гірняк // Обладнання та технології харчових виробництв 2010. - Вип. 25 - 384 с.

4. Решетило Л.І. Виробництво та споживання йогурту в Україні / Л.І. Решетило, О.І. Заєць // Науковий вісник НЛТУ України - 2011. - Вип.21.6 - С. 291-293.

5. Дідух, Н.А. Обгрунтування складу заквашувальної композиції для виробництва ацидофільних кисломолочних продуктів для дитячого харчування [Текст] / Н.А. Дідух, А.С. Авершина // Наук. праці ОНАХТ. - Одеса, ОНАХТ. - 2012. - Вип. 42. - Т.2.

6. Державний комітет статистики України: сільське господарство// режим доступу: 
http://www.ukrstat.gov.ua.

7 ТОП-10 найбільших виробників молочної продукції в Україні // Аграрне інформаційне агентство «Agravery» - 2016, [Електронний ресурс] - Режим доступу: http://agravery.com/uk/posts/show/top-10-najbilsih-virobnikiv-molocnoi-produkcii-v-ukraini

8. Вісник молочників - 2016, [Електронний ресурс] - Режим доступу: http://www.ukrmolprom.kiev.ua/ua/analitika/shchomisyachnanalitika/category/2016

9. Офіційний сайт Державного комітету статистики України. [Електронний ресурс] - Режим доступу: http://www.ukrstat.gov.ua

10. Світовий ринок і місце молока на ньому // Мілк-юа - 2016 [Електронний pecypc] - Режим доступу: http://milkua.info/ru/post/mirovoj-rynok-moloka-i-mesto-ukrainy-nanem

Цель. Исследование динамики развития рынка кисломолочной продукции, а также факторов, влияющих на потребительские свойства продукта и его привлекательность.

Методики. Для определения показателей потребительских свойств использовали органолептические, физико-химические и микробиологические методы исследования в соответствии с действующей нормативной документации Украины. Исследование рынка проводили по стандартным методикам.

Результаты. Проанализировань существующие подходы по улучшению качества исследуемого продукта. Одним из способов повышения потребительских свойств определена корректировка качества с применением различных наполнителей, например, компонентов животного (молоко, закваски, творог) и растительного (фрукты,, ягоды, овощи, специи) происхождения. Кроме этого путем повышения пищевой иенности кисломолочных продуктов является обогащение их состав белковыми, углеводными и минеральными компонентами.

Практическая значимость. Полученные результаты исследований могут быть использованы в работе отечественных предприятий-производителей молочной продукции.

Ключевые слова: кисломолочная продукиия, дефекты, качество, потребительские свойства, рынок.

Purpose. Research of dynamics the development of the market of sour-milk products, as well as factors that are influencing to the consumer properties of the product and its attractiveness.

Method. For determine the indicators of consumer properties were used organoleptic, physico-chemical and microbiological research methods in accordance with the current normative documentation of Ukraine. Market research was conducted according to standard methods.

Results. Was analyzed the existing approaches to improving the quality of the researched product. One of the ways to improve the consumer properties was defined the quality adjustment with using a variety of fillers, for example, components of animal (milk, leaven, cheese) and vegetable (fruits, berries, vegetables, spices) origin. In addition, another way of improving the nutritional value of sour-milk products is to enrich their composition with protein, carbohydrate and mineral components.

Practical significance. The obtained research results can be used in the work of domestic enterprises producing dairy products.

Key words: sour-milk products, defects, quality, consumer properties, market.

Рекомендовано до публікаиії докт.техн.наук. професором Луиького НТУ Байдаковою Л.I. Дата надходження в редакцію 31.01.2018 